\title{
Effects of wave exposure on population structure, demography, biomass and productivity of the kelp Laminaria hyperborea
}

\author{
Morten F. Pedersen ${ }^{1, *}$, Lars B. Nejrup ${ }^{1}$, Stein Fredriksen ${ }^{2}$, Hartvig Christie ${ }^{3}$, \\ Kjell Magnus Norderhaug ${ }^{3}$ \\ ${ }^{1}$ Centre for Integrated Population Ecology (CIPE), Department of Environmental, Social \& Spatial Change (ENSPAC), \\ Roskilde University, Box 260, Roskilde 4000, Denmark \\ ${ }^{2}$ Department of Biology, Oslo University, Box 1072, Blinderen, Oslo 0316, Norway \\ ${ }^{3}$ Norwegian Institute for Water Research (NIVA), Gaustadaleen 21, Oslo 0349, Norway
}

\begin{abstract}
Patterns of potential recruitment, survival, age-structure, density, biomass and primary production were studied in the kelp Laminaria hyperborea along a wave-exposure gradient in western Norway. The distribution of $L$. hyperborea is positively related to wave exposure, and the present work aimed to study how demography and population dynamics are affected by wave exposure. Populations at 9 sites representing 3 different levels of wave exposure were investigated. The biomass and production of $L$. hyperborea doubled along the gradient from low- to high-exposure sites. This increase was caused by an increase in plant density and individual plant size. Recruits and sub-canopy plants made up the majority of all individuals at all sites, but potential recruitment increased more than mortality rate among recruits and young sub-canopy plants as wave exposure increased, leading to a higher density of these small individuals at highexposure sites. Despite their large numbers, recruits and sub-canopy plants were not important for total biomass and production, and variations in those parameters with wave exposure were largely driven by variations in the density and size of adult canopy plants. Canopy plants suffered higher rates of mortality at low wave exposure, leading to shorter longevity and lower density than at high-exposure sites. The density and individual size of canopy plants both increased by ca. $50 \%$ with increasing wave exposure, explaining the higher biomass and productivity at highexposure sites. We suggest that the high mortality rate, low density and small size of canopy plants at low-exposure sites is caused by a combination of high epiphytic load and self-shading, which may impair light conditions, affect nutrient uptake and increase drag on the blades during extreme wind events. The reason why plants at high-exposure sites reach a larger individual size remains unknown.
\end{abstract}

KEY WORDS: Macroalgae $\cdot$ Physical disturbance $\cdot$ Population dynamics · Demography $\cdot$ Biomass · Productivity

Resale or republication not permitted without written consent of the publisher

\section{INTRODUCTION}

Kelp forests rank among the most productive and diverse ecosystems on earth and are found along temperate and arctic coastlines of South America, Australia, North America, South Africa and Europe
(Steneck et al. 2002). Laminaria is the most common genus of kelp in Europe, and L. hyperborea is distributed from Portugal (Kain 1971) to the Murman coast of the Barents Sea (Schoschina 1997). The Norwegian population of $L$. hyperborea has been estimated to cover an area of almost $6000 \mathrm{~km}^{2}$ (Gundersen et al. 
2010). The Norwegian kelp forests are highly productive, with an estimated annual production exceeding $2000 \mathrm{~g}$ dry weight (DW) $\mathrm{m}^{-2}$ (Sjøtun et al. 1995, Abdullah \& Fredriksen 2004). The high production of organic matter and the 3D structure created by kelp supports a rich and diverse fauna, including several economically important species that use L. hyperborea forests as a habitat or as nursery grounds (Christie et al. 2003, Fredriksen 2003, Norderhaug et al. 2005).

The distribution and performance of kelp are regulated by a large number of environmental factors. Rocky substrate is a prerequisite for the presence of kelp. Water temperature, light and day length seem important for the latitudinal (i.e. north to south) distribution and growth performance of Laminaria hyperborea (Rinde \& Sjøtun 2005), while the local light climate, topography, water depth and sometimes salinity set the overall limits for the vertical and areal distribution of kelp on a regional and local scale (Lüning 1990). Wave exposure also affects the vertical distribution (Kain 1971) and morphology (Svendsen \& Kain 1971, Sjøtun \& Fredriksen 1995) of L. hyperborea. Populations of L. hyperborea are poorly developed or absent in areas with low exposure (e.g. inner fjords and sheltered bays) but become more dense and better developed as wave exposure increases (Kain 1971, Svendsen \& Kain 1971). A study by Bekkby et al. (2009) confirmed recently that the local distribution of L. hyperborea is positively affected by wave exposure and that wave exposure is almost as important as water depth and substrate type for predicting its presence. These observations indicate that the population properties (e.g. recruitment, survival, biomass, productivity, etc.) of $L$. hyperborea are positively affected by wave exposure, but no study has yet attempted to quantify such effects of wave exposure. Moderate wave exposure may affect submerged macrophytes positively through a reduction of the stagnant boundary layer around the leaves or the thallus, which may stimulate the uptake of inorganic carbon and nutrients and, thus, photosynthesis and growth (Hurd 2000). Water movement may also stimulate the photosynthesis and growth of plants in dense stands by moving them back and forth so that light can reach individuals that would otherwise suffer from shading. Strong wave exposure may, in contrast, have an adverse effect on submerged plants because plants, or plant parts, may be torn from the substrate and removed from the population. High wave exposure may also resuspend sediments, increase turbidity and, thus, affect the local light climate negatively. The net effects of wave exposure on kelp biomass, productivity and population dynamics may therefore be positive or negative, depending on the level of water movement, the plant species and the environmental settings in question.

The aim of this work was to study how wave exposure affects population properties of kelp, Laminaria hyperborea. More specifically, we wanted to find out how wave exposure influenced the population structure, population dynamics, growth and production of the L. hyperborea. To answer these questions, we performed extensive sampling and analyses of kelp from 9 sites with 3 different levels of wave exposure.

\section{MATERIALS AND METHODS}

\section{Study site and estimates of wave exposure}

This study was carried out in the archipelago outside Molde $\left(62^{\circ} 50^{\prime} \mathrm{N}, 6^{\circ} 30^{\prime} \mathrm{E}\right)$ on the west coast of Norway (Fig. 1). The water depth in the area ranges from 0 to $100 \mathrm{~m}$, and the substrate is mainly rocky

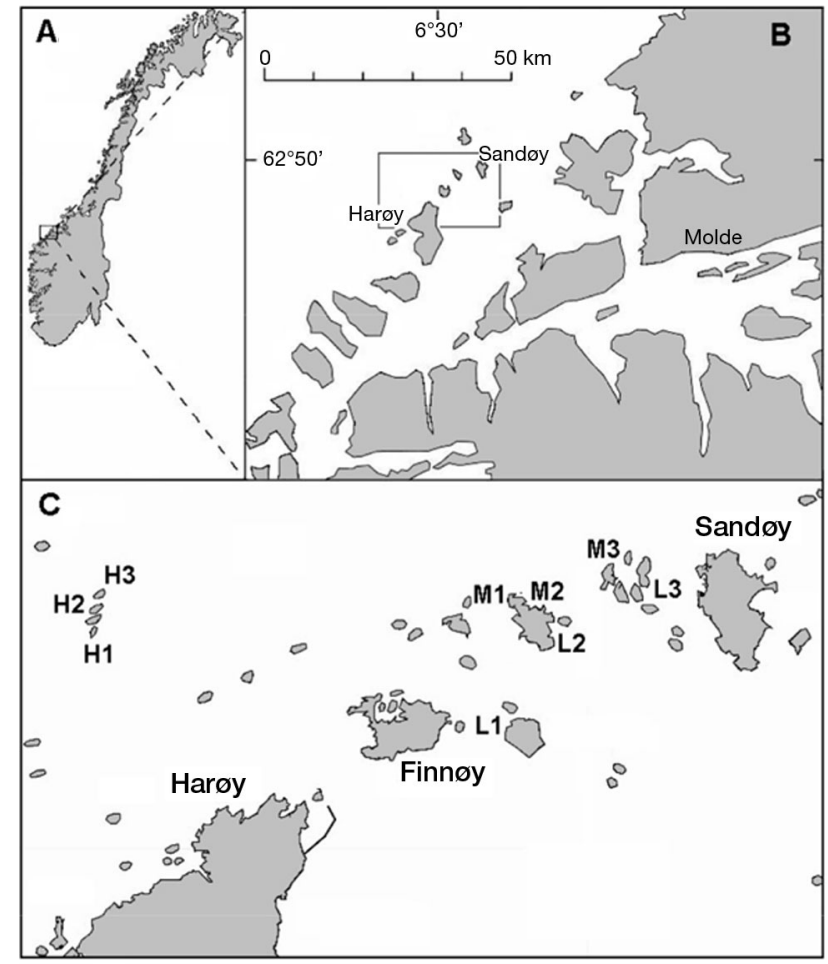

Fig. 1. The study area in the Molde archipelago, western Norway. (A) Norway and (B) the Molde archipelago with an indication of the study area. (C) The 9 study sites situated around and between the islands of Harøy, Finnøy and Sandøy. Exposure sites: L1 to L3 = low, M1 to M3 = intermediate and $\mathrm{H} 1$ to $\mathrm{H} 3$ = high wave exposure 
with sandy bottom in between the islands. The westward coastlines of the islands (facing the Norwegian Sea) are heavily exposed to waves and ocean swells, while less-exposed sites are found on the eastern sites of the islands. Laminaria hyperborea is abundant in the sub-tidal zone, where it penetrates to ca. $20 \mathrm{~m}$ of depth. Small patches of Saccharina latissima and Saccorhiza polyschides occur here, especially at the lower depth range of L. hyperborea and in the most sheltered locations.

Samples were collected from sites situated close to small islands around the larger islands of Harøy and Sandøy. A total of 9 sites were chosen to represent 3 levels of wave exposure (low, intermediate and high) with 3 replicate sites in each level. Useable sites were identified from GIS maps of relative wave exposure (RWE) in the area. The RWE was mapped with a spatial resolution of $10 \mathrm{~m}$ using a 'simplified wave model' that uses fetch, wind speed and frequency in 16 compass directions as input data (Isæus 2004, Bekkby et al. 2008):

$$
\mathrm{RWE}=\frac{1}{16} \sum_{i=1}^{16} F_{i} \times W_{i} \times f_{i}
$$

where $F_{i}$ is fetch (in meters), $W_{i}$ is the average wind speed (in $\mathrm{m} \mathrm{s}^{-1}$ ), and $f_{i}$ is the wind frequency (relative amount of time that wind came from a specific direction) in compass sector i. Data for wind speed and direction were obtained from the Norwegian Meteorological Institute and averaged over a 5 yr period. Predicted wave exposure levels (Table 1) ranged from 'sheltered' to 'very exposed' according to the classes used by the EUNIS system for coastal habitat classification in Europe (Davies \& Moss 2003). The model was originally validated in the Stockholm archipelago (Isæus 2004) and has since been used to predict wave exposure in the Norwegian mapping program on marine biodiversity (e.g. Rinde et al. 2006).

\section{Sampling}

Samples were collected between June and September 2006 after the establishment of recruits and after the main growth period of Laminaria hyperborea. At each site, all of the plants seen by SCUBA divers were collected within 6 to 8 frames with an area of $1 \mathrm{~m}^{2}$ each. The frames were placed haphazardly within the forest by swimming above the forest and dropping them randomly with a minimum distance of 10 to $20 \mathrm{~m}$ apart. All of the samples were taken at 5 to $7 \mathrm{~m}$ depth and brought back to the field station and processed immediately. The number of plants in each sample was counted, and the length of the stipe was measured for each individual. The plants were subsequently divided into holdfast, stipe and blade and weighed (blotted fresh weight). The total biomass in each sample was estimated as the sum of all individual weights. We aged all individuals by counting the age rings in the lower part of the stipe (Kain 1963). In total, 5920 plants were measured and aged.

\section{Population analysis}

Populations of Laminaria hyperborea can be considered to be composed of at least 3 distinct groups (stages) of individuals: recruits, sub-canopy plants and canopy individuals. Therefore, population parameters were estimated for each stage. Recruits were defined as small individuals without age rings (i.e. $<1$ yr old). Sub-canopy plants are older, but relatively small individuals, that live beneath tall, canopyforming individuals. Sub-canopy plants can remain alive for years, hardly growing (e.g. Sjøtun et al. 2006), but may initiate rapid growth if space (and light) becomes available by the removal of canopy individuals. Canopy plants are tall, older individuals

Table 1. Study sites, their location and estimated wave exposure levels

\begin{tabular}{|c|c|c|c|c|}
\hline $\begin{array}{l}\text { Exposure } \\
\text { level }\end{array}$ & Stn & Position & On site & $\begin{array}{l}\text { Wave exposure }\left(\mathrm{m}^{2} \mathrm{~s}^{-1}\right) \\
\text { Mean } \pm \mathrm{SD}\end{array}$ \\
\hline Low & $\begin{array}{l}\text { S1 } \\
\text { S2 } \\
\text { S3 }\end{array}$ & $\begin{array}{l}62^{\circ} 47.987^{\prime} \mathrm{N}, 6^{\circ} 31.572^{\prime} \mathrm{E} \\
62^{\circ} 48.873^{\prime} \mathrm{N}, 6^{\circ} 32.156^{\prime} \mathrm{E} \\
62^{\circ} 49.133^{\prime} \mathrm{N}, 6^{\circ} 33.384^{\prime} \mathrm{E}\end{array}$ & $\begin{array}{l}2.5 \times 10^{5} \\
0.7 \times 10^{5} \\
0.7 \times 10^{5}\end{array}$ & $1.3 \times 10^{5} \pm 0.6 \times 10^{5}$ \\
\hline Intermediate & $\begin{array}{l}\text { M1 } \\
\text { M2 } \\
\text { M3 }\end{array}$ & $\begin{array}{l}62^{\circ} 48.941^{\prime} \mathrm{N}, 6^{\circ} 30.663^{\prime} \mathrm{E} \\
62^{\circ} 49.028^{\prime} \mathrm{N}, 6^{\circ} 31.781^{\prime} \mathrm{E} \\
62^{\circ} 49.398^{\prime} \mathrm{N}, 6^{\circ} 33.092^{\prime} \mathrm{E}\end{array}$ & $\begin{array}{l}4.7 \times 10^{5} \\
4.7 \times 10^{5} \\
5.0 \times 10^{5}\end{array}$ & $4.8 \times 10^{5} \pm 0.1 \times 10^{5}$ \\
\hline High & $\begin{array}{l}\text { E1 } \\
\text { E2 } \\
\text { E3 }\end{array}$ & $\begin{array}{l}62^{\circ} 48.427^{\prime} \mathrm{N}, 6^{\circ} 24.492^{\prime} \mathrm{E} \\
62^{\circ} 48.495^{\prime} \mathrm{N}, 6^{\circ} 24.692^{\prime} \mathrm{E} \\
62^{\circ} 48.554^{\prime} \mathrm{N}, 6^{\circ} 24.282^{\prime} \mathrm{E}\end{array}$ & $\begin{aligned} 9.3 & \times 10^{5} \\
9.0 & \times 10^{5} \\
11.6 & \times 10^{5}\end{aligned}$ & $9.7 \times 10^{5} \pm 1.4 \times 10^{5}$ \\
\hline
\end{tabular}


that form a dense canopy layer. Because the morphology and growth patterns differ among the stages, we chose to treat them separately when analyzing the population dynamics.

Individuals were designated to one of the 3 stages based on their age (recruits only; $<1$ yr old) or their stipe length. Stipe growth is fast when sufficient space and light are available but slows down and stops when the plant reaches the canopy layer (Kain 1963, 1967). Mean stipe length in each age class (Fig. 2) can therefore be used to separate sub-canopy from canopy plants (Rinde \& Sjøtun 2005). For all data collected at a site, we plotted age-specific stipe length $(L)$ against age and fitted the Gompertz function (Eq. 2) to the data using non-linear, least-squares regression:

$$
L=L_{\infty} \exp \{-\exp [-k(x-M)]\}
$$
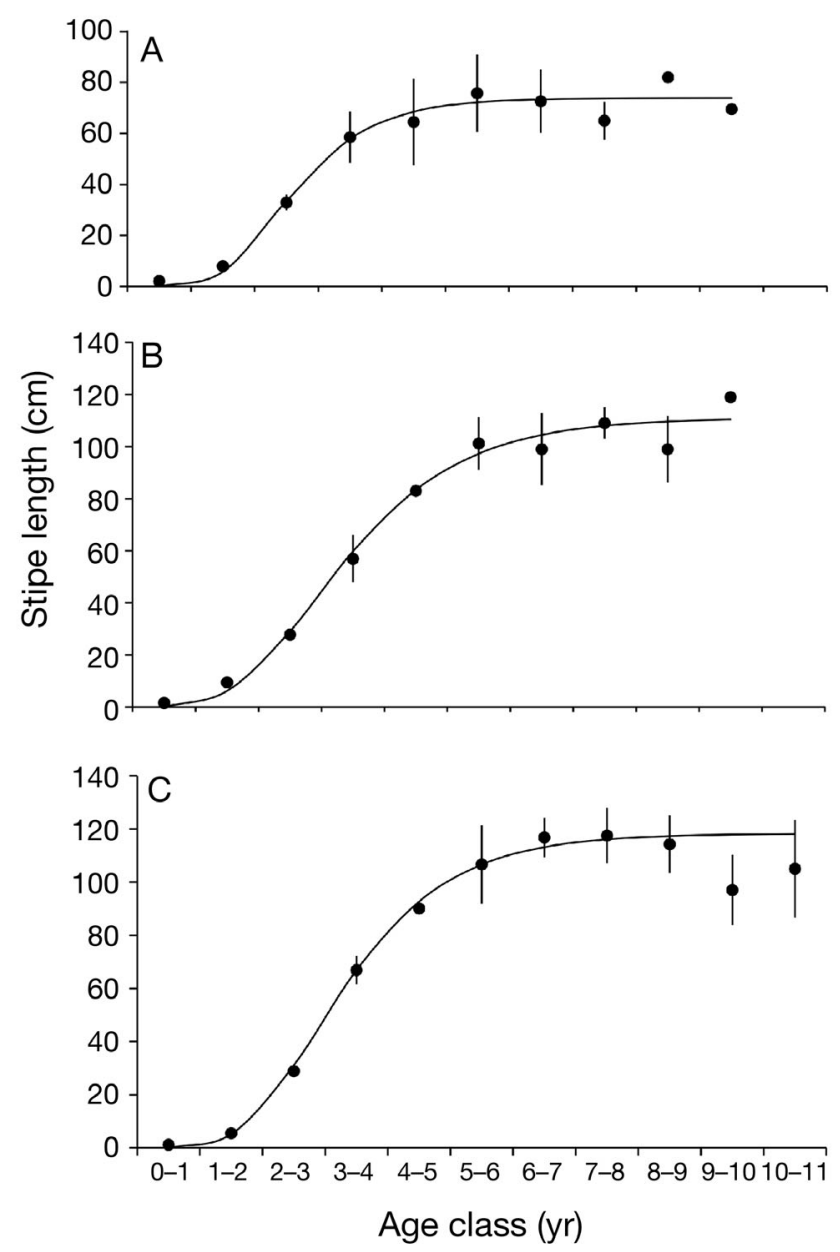

Fig. 2. Laminaria hyperborea. Stipe length plotted against age of the plants exposed to (A) low, (B) intermediate and (C) high wave exposure. Overall means $\pm \mathrm{SD}$, each based on the mean values from 3 replicate sites within each level of exposure. Curves are fits of the Gompertz function (Eq. 2) where $L_{\infty}$ is the asymptotic stipe length $(\mathrm{cm}), k$ is a growth constant describing the stipe growth rate $\left(\mathrm{yr}^{-1}\right), \mathrm{x}$ is the mean age, and $M$ is the mean age ( $\left.\mathrm{yr}\right)$ at which maximum stipe growth occurs.

Sub-canopy plants were then defined as those having a stipe shorter than the estimated mean length at age $M+1$ (in yr), whereas canopy plants were identified as those having a stipe equal to or longer than the estimated mean length at age $M+1$ (Rinde \& Sjøtun 2005). The plant density $\left(\mathrm{m}^{-2}\right)$, individual biomass ( $\mathrm{g}$ fresh weight $[\mathrm{FW}]$ per individual) and biomass $\left(\mathrm{g} \mathrm{FW} \mathrm{m}^{-2}\right.$ ) was finally estimated for recruits, sub-canopy and canopy plants separately in each sample from all 9 sites.

Population dynamics were studied using a 'static' life-table approach in which one census was used to quantify the density of individuals belonging to different age classes (age-based catch curve). Such data can be used to estimate the instantaneous mortality rate $(Z)$ of the population, assuming a stable agestructure (Beverton \& Holt 1957, 1959), by fitting a logarithmic model to the right-hand descending part of the catch curve:

$$
N_{t}=N_{0} \times \mathrm{e}^{-Z \times t}
$$

where $Z$ is the mortality rate, $t$ is age (in yr), $N_{t}$ is the density of plants at age $t$, and $N_{0}$ is the density of plants at $t=0$. When Eq. (3) is fitted to the catch curve of sub-canopy plants, $N_{0}$ may provide an average estimate of the initial density of recruits. This method integrates information of births and deaths over the lifetime of the population, i.e. over the preceding $6 \mathrm{yr}$ for the sub-canopy plants and $11 \mathrm{yr}$ prior to the sampling time in the case of the canopy plants.

Estimates of population mortality rate and initial density of recruits rely on the assumption of a stable age-structure over the lifetime of the population. No population has a $100 \%$ stable age-structure over longer time-scales, but good fits of Eq. (3) to the catch curves from each site indicate that the age-structure has remained relatively stable over a time-scale equal to the lifespan of the population. If not, some cohorts would deviate substantially from the logarithmic decline in numbers with increasing age, and the fit would be poor. All of the fits (i.e. logarithmic model fitted to catch curves) performed in this study were highly significant $(p<0.001)$, and all but one had $R^{2}$ values $>0.9$, indicating that the age-structure of the studied Laminaria populations remained rather constant over longer time-scales (here, 6 to $11 \mathrm{yr})$. Although the 'static' life-table approach is considered less accurate than the 'dynamic' life-table 
approach, in which 1 cohort is followed through its life and survival or mortality are estimated 'continuously', this method is commonly used to study the population dynamics of organisms with a long lifespan for which following one cohort over many successive years is impractical.

The observed density of recruits was considered to equal recruitment, but this may substantially underestimate true recruitment because initial recruit mortality (in early spring) may be high and because it is difficult to sample these small individuals efficiently under water. Potential recruitment was instead estimated for each site using the age-based catch curves for sub-canopy plants and Eq. (3). Potential recruitment was estimated for each site based on the pooled data from all samples from that site to obtain proper fits. All recruits are, by definition, either lost by mortality or by transition of individuals into the subcanopy stage within $1 \mathrm{yr}$. The loss of recruits by transition to the sub-canopy stage was set as equal to the absolute loss of sub-canopy plants on an annual basis, assuming a constant density of sub-canopy plants from year to year. The absolute mortality of recruits $\left(\mathrm{m}^{-2} \mathrm{yr}^{-1}\right)$ was estimated as the difference between recruitment and losses due to transition.

Input of recruits into the sub-canopy stage was, as mentioned, assumed to equal the absolute loss of sub-canopy plants, whereas the absolute loss of subcanopy plants through transition into the canopy stage was assumed to be equal to the absolute annual loss of canopy plants. Instantaneous mortality rates were estimated separately for sub-canopy $\left(Z_{\mathrm{SC}}\right)$ and canopy plants $\left(Z_{C}\right)$ at each site, by fitting Eq. (3) to the right-hand descending part of the age-based catch curves (for sub-canopy and canopy plants, separately). For sub-canopy plants, the mortality rate $\left(Z_{\mathrm{SC}}\right)$ includes both losses due to mortality and losses due to transition (into the canopy stage). The absolute loss of sub-canopy plants through mortality was estimated as the difference between the total absolute losses (estimated from $Z_{\mathrm{SC}}$ and the density of canopy plants) and losses through transition. The absolute mortality rate of canopy plants was estimated from mortality rates $\left(Z_{\mathrm{C}}\right)$ and the density of canopy plants using Eq. (3).

Annual estimates of production were made for entire populations (i.e. recruits, sub-canopy and canopy plants together) at each site. Production was estimated from age-specific biomass properties. Annual blade production was simply estimated from the total biomass of blades because Laminaria hyperborea plants discharge their blades every winter and subsequently produce new blades that reach maxi- mum size in late spring. The annual production (g FW m ${ }^{-2} \mathrm{yr}^{-1}$ ) of holdfasts and stipes, respectively, was estimated as the difference between the agespecific mean weights (across individuals) of holdfasts or stipes (g FW holdfast ${ }^{-1}$ or stipe $^{-1}$ ) of successive age groups, multiplied by the density $\left(\mathrm{m}^{-2}\right)$ of the older of the 2 age groups and summed across all age classes, i.e.:

$$
\text { Production }=\sum_{t=1}^{n}\left(\bar{B}_{t+1}-\bar{B}_{t}\right) \times N_{t+1}
$$

where $B_{t}$ and $B_{t+1}$ are the mean biomass of either the holdfasts or stipes of individuals belonging to age class $t$ and age class $t+1$, respectively, and $N_{t+1}$ is the density of plants in the older of the 2 age classes (i.e. age class $t+1)$. These estimates are conservative because plant density decreased substantially with age. Total annual production ( $\mathrm{FW} \mathrm{m} \mathrm{m}^{-2} \mathrm{yr}^{-1}$ ) was finally estimated for each site by summing up the separate production estimates for holdfasts, stipes and blades.

\section{Statistical analysis}

Response parameters that could be quantified in each sample (density, age, individual biomass and total biomass per unit area) were compared across levels of wave exposure using nested ANOVA $(\alpha=$ 0.05). The main factor (wave exposure) was regarded a fixed factor, while 'site' was regarded a random factor nested within wave exposure. For the remaining response parameters (potential number of recruits, instantaneous mortality rates, absolute losses, mortality, transition and total production), we had only one number per site because these parameters were obtained from fitting equations (Eqs. 3 \& 4) to data that were pooled across all of the samples within each site to obtain proper fits. These response parameters were therefore compared across levels of exposure with 1-factor ANOVA $(\alpha=0.05)$ using the derived values from each site as input $(\mathrm{n}=3$ for each level of exposure). Tukey's multiple comparison test was used to compare individual means if the ANOVA indicated significant differences between site means. A Kolmogorov-Smirnov test was used to test if the data were normally distributed, and Levene's test was used to test for homogeneity of variances prior to analysis (Quinn \& Keough 2002). The data were natural logarithm (ln)-transformed to obtain normality or homogeneity of variances when necessary. Ratios (i.e. data for the relative contribution of various plant parts to the total individual biomass) were arcsinetransformed before analysis. 


\section{RESULTS}

\section{Stipe length and separation of sub-canopy and canopy individuals}

Stipe length increased with age at all exposure levels (Fig. 2) until the plants became 5 to 7 yr old. Canopy plants were relatively short at low wave exposure (mean length ca. $75 \mathrm{~cm}$ ) but became significantly taller at intermediate and high wave exposure (mean length 100 to $112 \mathrm{~cm}$, Table 2). Stipe length was used to separate plants into sub-canopy and canopy individuals by fitting the Gompertz growth function to the data in Fig. 2. Asymptotic stipe length $\left(L_{\infty}\right)$ increased with exposure and corresponded well to the observed maximum lengths (Table 2). Neither stipe growth rate $(k)$ nor the age at maximum stipe growth $(M)$ changed significantly with wave exposure. The mean stipe length for plants at age $M+1$ (age at maximum growth plus 1 yr) was finally used as a cut-off point to separate sub-canopy plants from canopy plants in each data set.

\section{Density}

Total plant density (Fig. 3, Table 3) increased significantly with wave exposure. All populations consisted of many small recruits and sub-canopy plants and a few large canopy individuals. Recruits and sub-canopy plants were more abundant at higher levels of exposure. The density of canopy plants increased from 7 to $8 \mathrm{~m}^{-2}$ at low and intermediate wave exposure to $12 \mathrm{~m}^{-2}$ at high wave exposure, but the variation among replicate sites was high, and dif-

Table 2. Observed mean stipe length of canopy plants $(L)$ and parameter estimates of $L_{\infty}$ (asymptotic stem length), $k$ (stem growth rate) and $M$ (age at maximum stem growth) obtained from fitting the Gompertz growth function (Eq. 2) to plots of mean stem length against age (Fig. 2). For each level of exposure, values are overall means \pm 1 SD each based on 3 site means (i.e. $n=3$ ). ANOVA results (nested ANOVA in the case of $L, 1$-way ANOVA in the case of $L_{\infty}, k$ and $M$ ) are given in the rightmost column. Different superscripts in brackets indicate heterogeneous groups according to Tukey's test

\begin{tabular}{|c|c|c|c|c|c|}
\hline & \multicolumn{3}{|c|}{ Wave exposure } & \multicolumn{2}{|c|}{ ANOVA results } \\
\hline & Low & Intermediate & High & $F$ & $\mathrm{p}$ \\
\hline$L(\mathrm{~cm})$ & $75.1 \pm 8.8^{(\mathrm{a})}$ & $101.6 \pm 11.5^{(\mathrm{b})}$ & $112.4 \pm 5.1^{(\mathrm{c})}$ & $F_{\mathrm{E} ; 2,6}=6.77$ & 0.029 \\
\hline$L_{\infty}(\mathrm{cm})$ & $78.6 \pm 6.7^{(\mathrm{a})}$ & $111.1 \pm 19.5^{(\mathrm{b})}$ & $118.8 \pm 11.4^{(\mathrm{b})}$ & $\begin{array}{l}F_{\mathrm{S}(\mathrm{E}) ; 6,54}=7.41 \\
F_{2,6}=7.41\end{array}$ & $\begin{array}{l}0.024 \\
0.024\end{array}$ \\
\hline$k\left(\mathrm{yr}^{-1}\right)$ & $1.0 \pm 0.4^{(\mathrm{a})}$ & $0.8 \pm 0.2^{(\mathrm{a})}$ & $0.9 \pm 0.0^{(\mathrm{a})}$ & $F_{2,6}=0.40$ & 0.516 \\
\hline$M(\mathrm{yr})$ & $2.9 \pm 0.2^{(\mathrm{a})}$ & $3.4 \pm 0.4^{(\mathrm{a})}$ & $3.4 \pm 0.2^{(\mathrm{a})}$ & $F_{2,6}=2.72$ & 0.145 \\
\hline
\end{tabular}

ferences were therefore only marginally significant. Variations in total density across levels of exposure were therefore mainly driven by variations in the density of recruits and sub-canopy individuals.

\section{Age-structure, recruitment and mortality}

The age-structure of populations from sites with different wave exposure differed slightly from each other because populations from intermediate- and high-exposure sites contained relatively more young individuals than those from low-exposure sites (Fig. 4). The age (mean $\pm \mathrm{SD}$ ) of sub-canopy plants (excluding recruits) decreased from $2.82 \pm 0.19 \mathrm{yr}$ at low exposure to $2.47 \pm 0.16 \mathrm{yr}$ at high exposure, whereas the mean age of canopy plants tended to increase with increasing exposure $(4.68 \pm 0.37 \mathrm{yr}$ at low exposure versus $5.39 \pm 0.08 \mathrm{yr}$ at high exposure). None of these differences were, however, statistically significant $(p=0.118)$. The oldest individuals $(11 \mathrm{yr}$ old) were found at high-exposure sites.

The population dynamics varied across levels of wave exposure (Table 4, Fig. 5). Potential recruitment at high-exposure sites was 4-fold higher than at sites with intermediate and low exposure, but the variation among replicate sites was large, and differences were therefore only marginally significant. The instantaneous mortality rate of recruits $\left(Z_{R}\right)$ was very high (3.21 to $3.36 \mathrm{ln}$ units $\mathrm{yr}^{-1}$, Table 4), leaving few survivors for transition into the sub-canopy fraction on an annual basis. The mortality rate of recruits and, hence, the proportion of recruits surviving and entering the sub-canopy stage did not differ significantly with wave exposure, but the absolute transition of recruits into the sub-canopy stage increased with wave exposure. The mortality rate of sub-canopy plants $\left(Z_{\mathrm{SC}}\right)$ was substantially lower than that of recruits $(1.07$ to $1.37 \mathrm{ln}$ units $\mathrm{yr}^{-1}$ ) and did not vary with wave exposure. A larger absolute input of individuals at highexposure sites combined with constant mortality rate across levels of exposure resulted in a higher steadystate density of sub-canopy plants with increasing exposure.

The annual input of sub-canopy plants into the canopy fraction and the absolute mortality of canopy plants were relatively low (4 to 5 plants $\mathrm{m}^{-2}$ $\mathrm{yr}^{-1}$ ) and similar across levels of expo- 

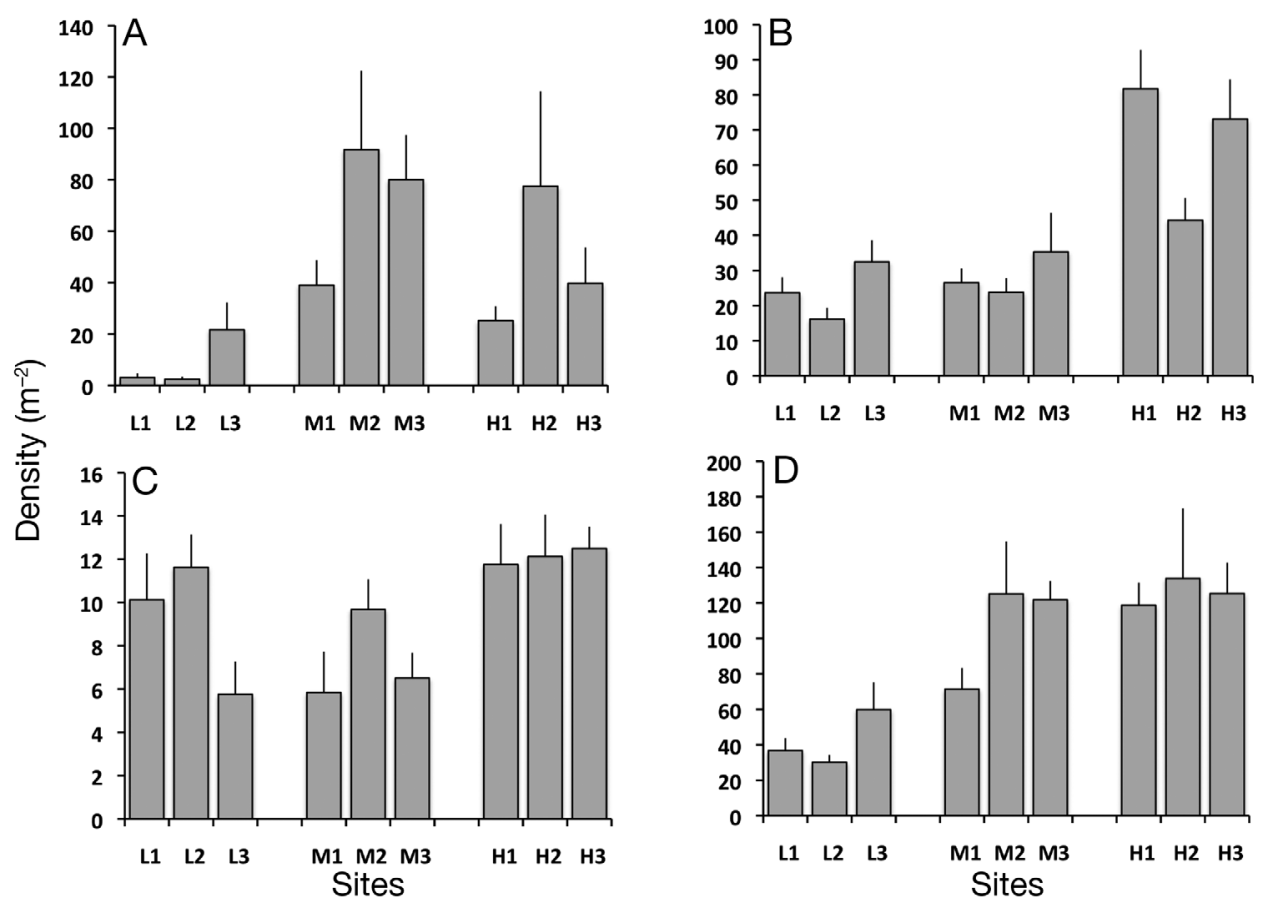

Fig. 3. Laminaria hyperborea. Observed density of (A) recruits, (B) subcanopy and (C) canopy plants, together with (D) total density at low- (L1 to 3), intermediate- (M1 to 3 ) and high- (H1 to 3 ) exposure sites. Means + $\mathrm{SE}$, each based on 6 to 8 replicates from each site

Table 3. Laminaria hyperborea. Results from nested ANOVA of the effect of wave exposure on the density of recruits, subcanopy plants, canopy plants and total plant density. SS $\mathrm{III}$ : type III sum of squares, MS: mean square. Wave exposure: L = low, $\mathrm{M}=$ intermediate, $\mathrm{H}=$ high

\begin{tabular}{|c|c|c|c|c|c|c|c|}
\hline Parameter & Source of variation & $\mathrm{SS}_{\text {III }}$ & $\mathrm{df}$ & MS & $F$ & $\mathrm{p}$ & Tukey \\
\hline Recruits & $\begin{array}{c}\text { Exposure } \\
\text { Site }_{(\exp )} \\
\text { Error }\end{array}$ & $\begin{array}{l}74.77 \\
14.43 \\
81.65\end{array}$ & $\begin{array}{r}2 \\
6 \\
57\end{array}$ & $\begin{array}{r}37.39 \\
2.40 \\
1.43\end{array}$ & $\begin{array}{r}15.546 \\
1.679\end{array}$ & $\begin{array}{l}0.004 \\
0.143\end{array}$ & $\mathrm{M}>\mathrm{H}>\mathrm{S}$ \\
\hline Sub-canopy plants & $\begin{array}{c}\text { Exposure } \\
\text { Site }_{(\exp )} \\
\text { Error }\end{array}$ & $\begin{array}{r}15.71 \\
4.90 \\
21.32\end{array}$ & $\begin{array}{r}2 \\
6 \\
57\end{array}$ & $\begin{array}{l}7.85 \\
0.82 \\
0.37\end{array}$ & $\begin{array}{l}9.608 \\
2.186\end{array}$ & $\begin{array}{l}0.013 \\
0.057\end{array}$ & $\mathrm{H}>\mathrm{M}=\mathrm{L}$ \\
\hline Canopy plants & $\begin{array}{l}\text { Exposure } \\
\text { Site }_{(\exp )} \\
\text { Error }\end{array}$ & $\begin{array}{r}248.7 \\
201.7 \\
1190.3\end{array}$ & $\begin{array}{r}2 \\
6 \\
57\end{array}$ & $\begin{array}{r}124.3 \\
33.6 \\
20.9\end{array}$ & $\begin{array}{l}3.699 \\
1.610\end{array}$ & $\begin{array}{l}0.089 \\
0.161\end{array}$ & ns \\
\hline Total density & $\begin{array}{c}\text { Exposure } \\
\text { Site }_{(\exp )} \\
\text { Error }\end{array}$ & $\begin{array}{r}17.77 \\
2.39 \\
13.96\end{array}$ & $\begin{array}{r}2 \\
6 \\
57\end{array}$ & $\begin{array}{l}8.89 \\
0.40 \\
0.24\end{array}$ & $\begin{array}{r}22.281 \\
1.628\end{array}$ & $\begin{array}{l}0.002 \\
0.156\end{array}$ & $\mathrm{H}=\mathrm{M}>\mathrm{L}$ \\
\hline
\end{tabular}

sure. The instantaneous mortality rate of canopy plants $\left(Z_{\mathrm{C}}\right)$ was lower than that of recruits and subcanopy plants (0.53 to $0.80 \ln$ units $\mathrm{yr}^{-1}$, Table 4 ) and tended, in contrast to absolute mortality, to decrease (by $30 \%$ ) with increasing wave exposure. Constant input of sub-canopy plants into the canopy across levels of exposure combined with lower rates of mortality at high-exposure sites resulted in a higher density of canopy plants at sites with high wave exposure.

\section{Individual plant biomass}

Individual plant biomass increased with age, but became more or less constant as the maximum stipe length was reached (compare Figs. $2 \& 6$ ). The individual biomass of canopy plants (Table 5) increased from ca. $820 \mathrm{~g} \mathrm{FW}$ at low-exposure sites to ca. $1250 \mathrm{~g}$ FW per plant at intermediate- and high-exposure sites. The changes in individual plant biomass of the canopy plants were based on an increase in the mass 


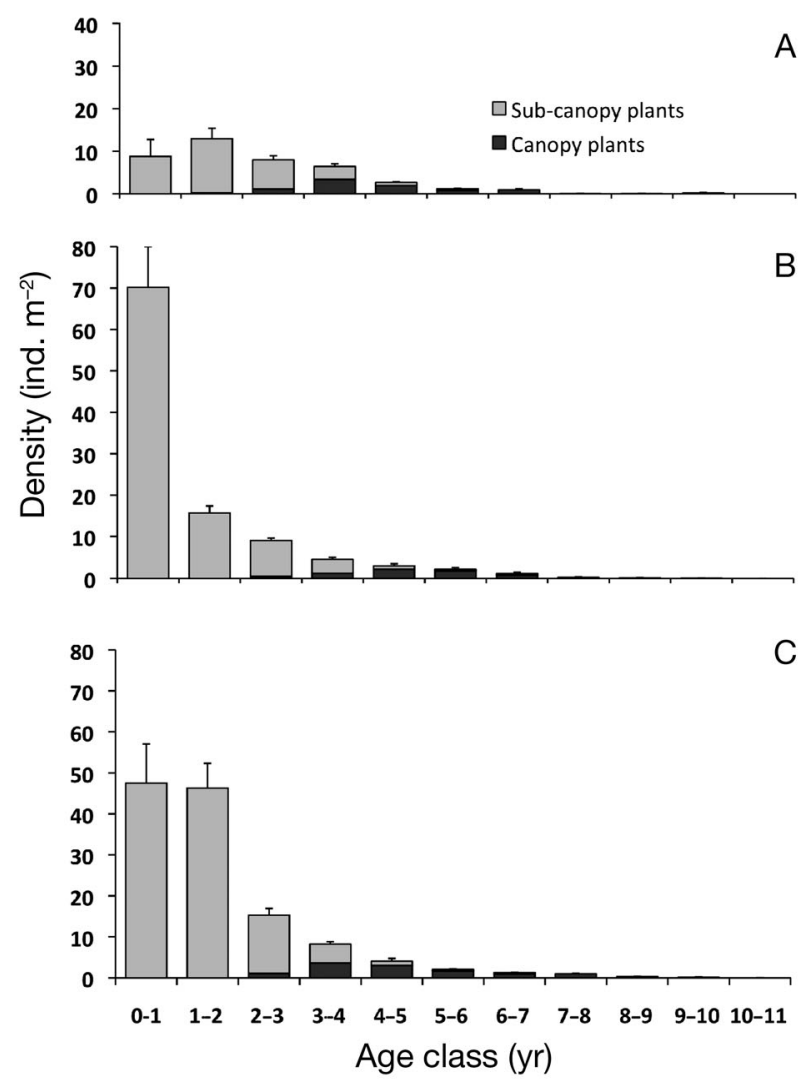

Fig. 4. Laminaria hyperborea. Age distributions of kelp populations exposed to (A) low, (B) intermediate and (C) high wave exposure, including recruits and sub-canopy plants (light grey) and canopy individuals (dark grey). Overall means $\pm \mathrm{SE}$, each based on the mean values from 3 replicate sites within each level of exposure

of the holdfast, stipe and blade. Plants from highexposure sites tended to allocate a larger proportion of their biomass to the holdfast and the stipe and less to the blade, compared to plants at low wave exposure (Table 5).

\section{Areal biomass and production}

The average biomass per unit area ranged from $9000 \mathrm{~g} \mathrm{FW} \mathrm{m}^{-2}$ at low exposure to $18000 \mathrm{~g} \mathrm{FW} \mathrm{m}^{-2}$ (Fig. 7, Table 6) at high wave exposure. The variation in total biomass per unit area across levels of exposure was based on a parallel increase in the biomass of holdfasts, stipes and blades. The annual production by Laminaria hyperborea (Fig. 8, Table 6) followed the same pattern as total biomass and increased from $6867 \mathrm{~g} \mathrm{FW} \mathrm{m}^{-2}$ at low exposure to $12449 \mathrm{~g} \mathrm{FW} \mathrm{m}^{-2}$ at high exposure. Wave exposure had the largest effect on the production of stipes, which was 2.5-fold higher at high exposure than at low exposure. Production of blades formed ca. 60 to $70 \%$ of the total production, depending on exposure level, whereas holdfasts and stipes together formed the remaining 32 to $42 \%$ of the total production.

\section{DISCUSSION}

Water motion may stimulate littoral and sub-littoral algae (Hurd 2000) and wave-exposed coastal communities are therefore often highly productive (Leigh et al. 1987). The presence of Laminaria hyperborea is positively correlated to wave exposure (Bekkby et al. 2009), and the present study showed that the performance of $L$. hyperborea is positively affected by wave exposure; total plant biomass and production per unit area doubled along the exposure gradient. The annual production reached 7 to $12.5 \mathrm{~kg} \mathrm{FW} \mathrm{m}^{-2}$, depending on exposure level, which corresponds to 1400 to $2500 \mathrm{~g} \mathrm{DW} \mathrm{m}^{-2}$ or 560 to $1000 \mathrm{~g} \mathrm{C} \mathrm{m}^{-2}$, ranking these kelp forests among the most productive systems on earth. The annual production measured here corresponds to rates reported for L. hyperborea in Scotland, England, Germany (Heligoland), Iceland and Norway (800 to $4000 \mathrm{~g} \mathrm{DW} \mathrm{m}^{-2} \mathrm{yr}^{-1}$; e.g. Lüning 1969, Jupp \& Drew 1974, Gunnarsson 1991, Sjøtun et al. 1995). Production of Laminaria is typically estimated from the observed maximum biomass of blades in summer (e.g. Borum et al. 2002) or from net changes in individual biomass with age (e.g. Sjøtun \& Fredriksen 1995), but these methods may underestimate true primary production. About 2 thirds of the annual production of L. hyperborea consists of the production of blades, but blades are eroded at their distal edge throughout their lifetime. Blade erosion has not been quantified in L. hyperborea, but Tala \& Edding (2005) showed that kelps Lessonia nigrescens and L. trabeculata, which are morphologically similar to L. hyperborea, lost as much as $20 \%$ and $50 \%$, respectively, of their annual blade production due to erosion. The methods used to quantify production in the present study may further underestimate true primary production because they do not include the loss of fixed carbon through exudation of DOC, which may amount to ca. $26 \%$ of the carbon fixed by L. hyperborea on an annual basis (Abdullah \& Fredriksen 2004). The production that we report for $L$. hyperborea may thus underestimate true primary production by 25 to $50 \%$.

The observed increase in biomass and production of Laminaria hyperborea along the wave-exposure gradient was driven by variations in both plant den- 
Table 4. Laminaria hyperborea. Potential recruitment, inputs due to transition, absolute mortality and instantaneous mortality rate $(Z)$ of recruits, sub-canopy plants and canopy plants, respectively. Overall means \pm 1 SD for each level of exposure, each based on 3 sites $(\mathrm{n}=3)$. Note that the instantaneous mortality rate of sub-canopy plants includes the loss of individuals due to transition. ANOVA results are based on 1-way ANOVA using derived values from each site as input data. Different superscripts in brackets indicate heterogeneous groups according to Tukey's test

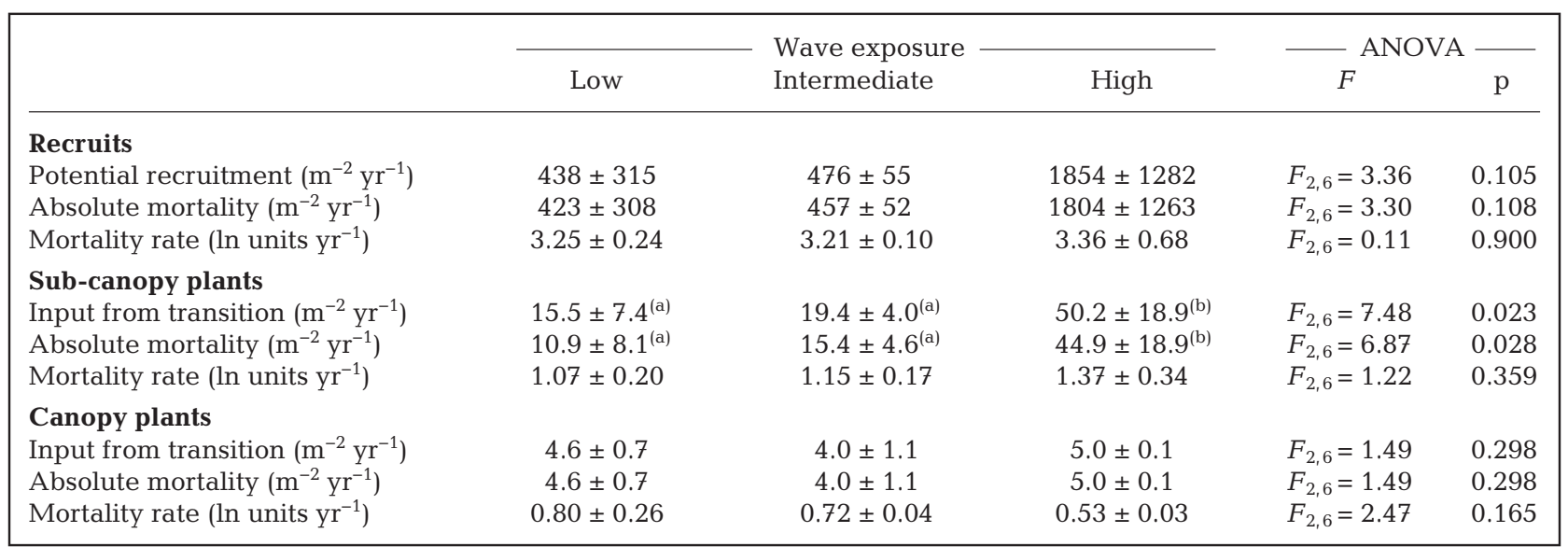

\section{Low wave exposure:}

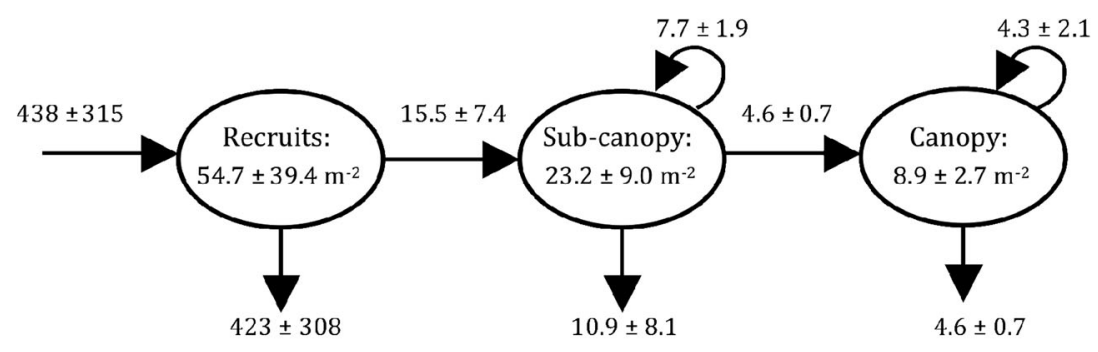

\section{Medium wave exposure:}

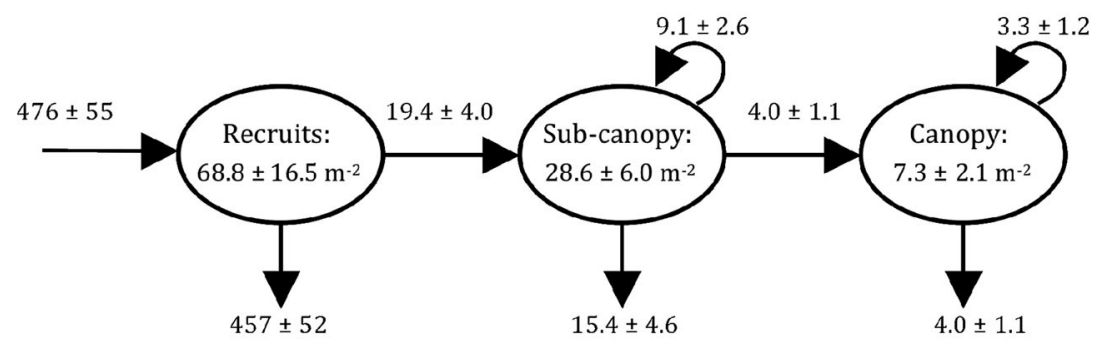

High wave exposure:

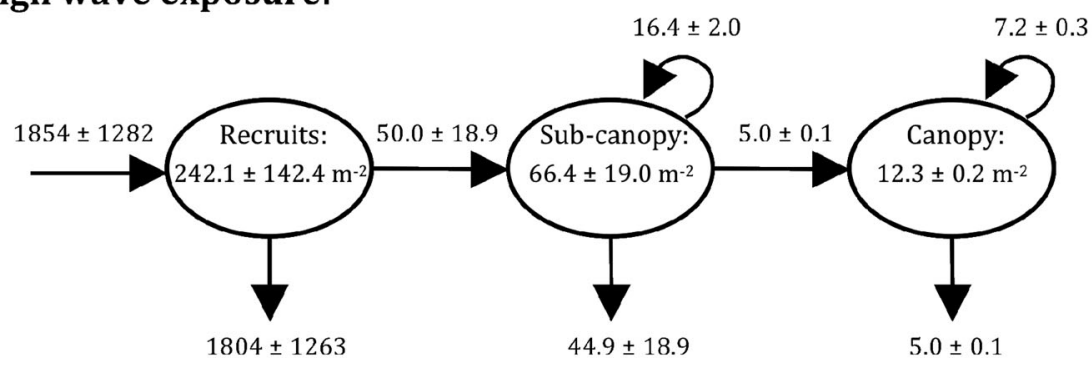

Fig. 5. Laminaria hyperborea. Conceptual model summarizing the annual population dynamics at low, intermediate and high wave exposure. Rates (arrows) are in units of ind. $\mathrm{m}^{-2} \mathrm{yr}^{-1}$, while numbers in ellipses (stages) are densities (ind. $\mathrm{m}^{-2}$ ). Horizontal arrows represent recruitment (in the case of recruits) or transitions from one stage to the next, while downward vertical arrows represent mortality. Arrows looping back to the same stage represent the number of individuals that remain within a stage within 1 yr. Mean values \pm 1 SD based on 3 replicate stations within each level of wave exposure 


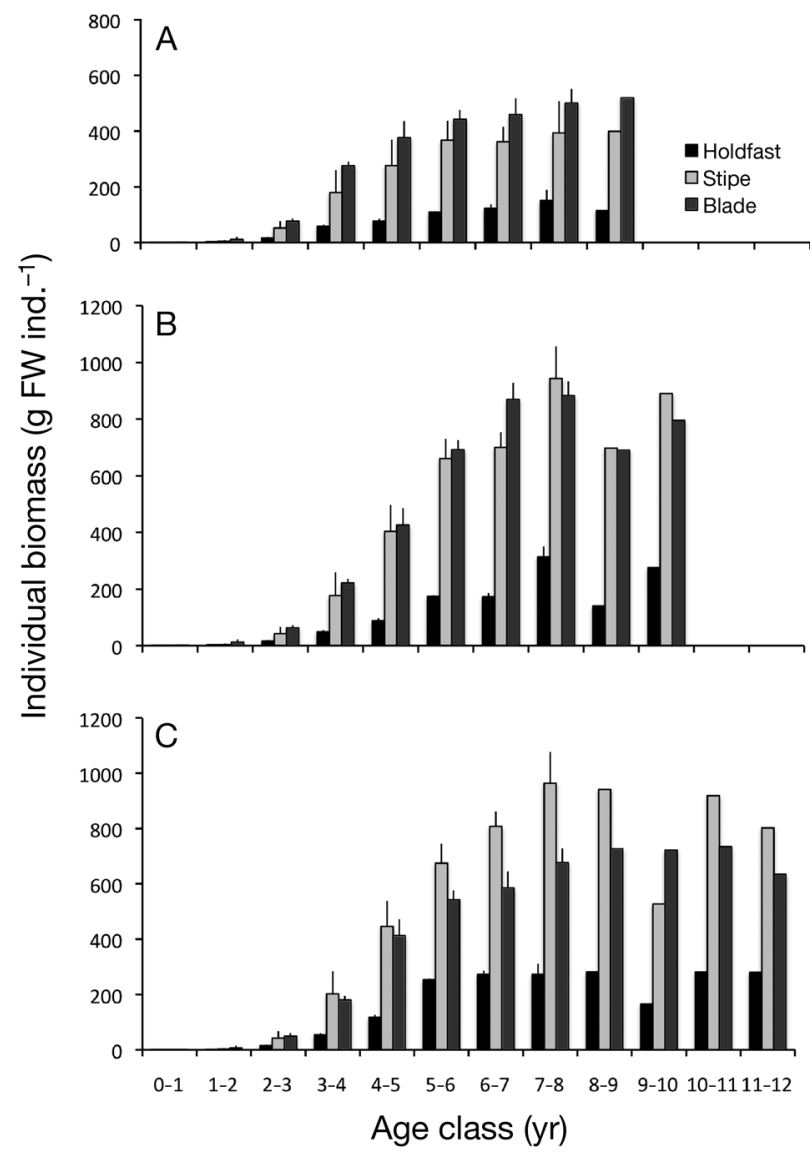

Fig. 6. Laminaria hyperborea. Individual biomass (g FW ind. ${ }^{-1}$ ) of the holdfast (black bars), stipe (light grey bars) and blade (dark grey bars) of plants with different age at (A) low, (B) intermediate and (C) high wave exposure. Overall means $+\mathrm{SD}$, each based on the mean values from 3 replicate sites within each level of exposure

sity and individual plant size. The processes that affect these parameters are thus driving the changes in biomass and production. Plant density increased significantly with exposure, but most of this change was caused by a significant increase in the number of recruits and sub-canopy individuals. These small individuals have little importance for total biomass and production, but they are important for the persistence of the population because they represent an 'inactive' reserve that can be mobilized to replace canopy plants that are lost (e.g. Sjøtun et al. 1998).

Plant density at any point in time reflects the balance between recruitment (or mobilization through transition) and losses due to mortality or to transition of individuals into the next stage. Recruitment is important for the persistence of populations, and higher recruitment leads to a high density of individuals unless mortality rate increases proportionally more than recruitment. The observed density of recruits increased with wave exposure but was lower than the recruitment predicted from the agestructure of sub-canopy plants, indicating that postsettlement mortality of recruits is high and that it occurs shortly after establishment. The low density of recruits could also indicate that we were unable to collect these small individuals efficiently. Kelp recruits suffer typically high rates of mortality (e.g. Reed \& Forester 1984, Dean et al. 1989, Reed 1990, Creed et al. 1998), and our numbers indicate that only a small percentage of the recruits would survive long enough to enter the sub-canopy stage. The estimated mortality rate of recruits was high but similar across levels of exposure, so variations in recruitment must have caused the observed differences in recruit density. Recruitment potential depends on spore production and, thus, on the density of sexually mature canopy plants. The entire study area is inhabited by kelp in the 3 to $20 \mathrm{~m}$ depth interval (Bekkby et al. 2009), and the production of spores by Laminaria hyperborea is magnificent: ca. $3 \times 10^{12}$ spores are produced annually in stands with 10 to 12 mature canopy plants per $\mathrm{m}^{2}$ (Kain 1975). Kelp spores can potentially disperse at the scale of several hundred meters to kilometers, depending on water motion (Fredriksen et al. 1995, Gaylord et al. 2002, Reed et al. 2004), but the majority of these spores may still settle relatively close to the spore-producing plants (Gaylord et al. 2006). In other words, recruit density should partially correlate to the density of reproducing canopy plants, which may explain why we found higher recruitment and density of recruits with increasing wave exposure. We finally stress that the potential recruitment presented here was estimated from the age-structures of sub-canopy plants and, thus, represents the average (over years) recruitment needed to obtain the observed age-structure and density. This method cannot capture inter-annual variations in recruitment that may vary considerably from year to year in other kelp species (e.g. Macrocystis pyrifera, Graham et al. 1997) and most likely also in L. hyperborea.

The absolute number of recruits that survived and moved into the sub-canopy stage per year represented only a very small fraction of the observed and potential number of recruits. The annual input of recruits into the sub-canopy stage increased with wave exposure, although the relative survival rate of recruits remained more or less constant across levels of exposure. As for recruits, the relative loss rates of sub-canopy plants (due to mortality and transition) remained basically constant across levels of exposure. The high density of sub-canopy plants found at 
high exposure was, in other words, caused by a higher absolute input (i.e. transition) of new individuals and not by variations in mortality rate across levels of exposure.

Table 5. Laminaria hyperborea. Biomass of individual plant parts in canopy plants and the proportion of total biomass that is allocated to the holdfast, stipe and blade at low, medium and high wave exposure, respectively. Overall means \pm 1 SD for each level of exposure, each based on 3 site means $(n=3)$. $\mathrm{FW}=$ freshweight. Nested ANOVA results are given in the rightmost column . Different superscripts in brackets indicate heterogeneous groups according to Tukey's test

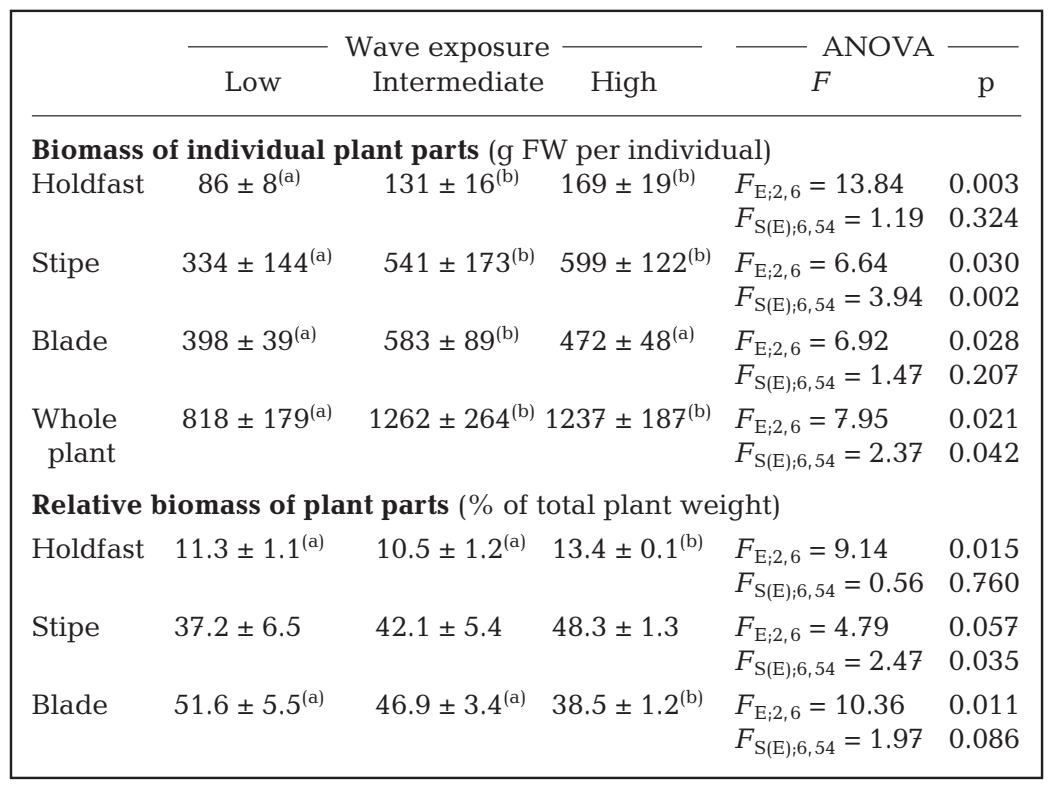

High mortality rates of sub-canopy individuals (here, 67 to $75 \%$ of all individuals annually) has been attributed to intra-specific competition for light between sub-canopy and canopy individuals because very little light penetrates the canopy layer in most kelp species (e.g. Norton et al. 1977, Gerard 1984, Reed \& Foster 1984, Dean 1985). Other factors, such as intra-specific competition among juveniles, inter-specific competition with other (sub-canopy) algal species and grazing have, however, also been shown to cause low survival among juvenile kelp (e.g. Reed \& Foster 1984, Dean et al. 1989, Reed 1990, Creed et al. 1998, Sjøtun et al. 2006).

The blade biomass of canopy plants per unit area increased almost 2-fold with wave exposure. We therefore initially expected that less light would penetrate the canopy and that subcanopy plants would suffer higher mortality rates at sites with high exposure. As mentioned, the mortality rate of recruits and sub-canopy plants did not vary significantly across levels of wave exposure and was related neither to the density of canopy plants ( $\mathrm{R}=-0.117, \mathrm{p}=0.765)$ nor to the biomass of their blades $(\mathrm{R}=0.081, \mathrm{p}=$ 0.836) when tested across all sites.

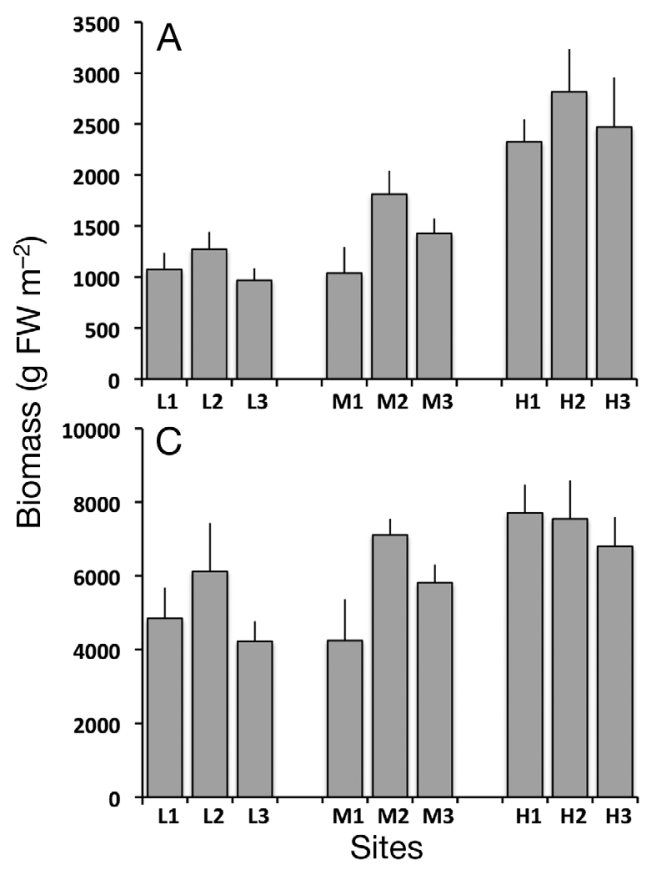

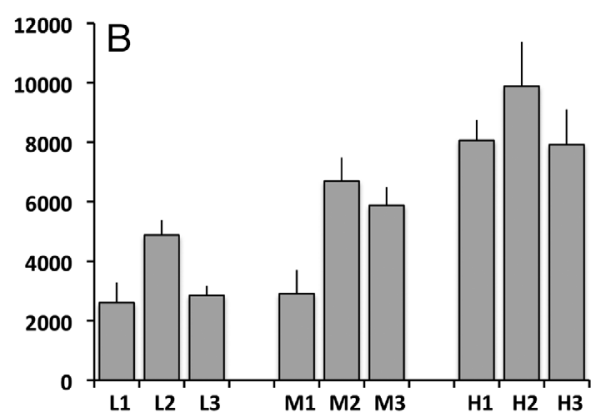

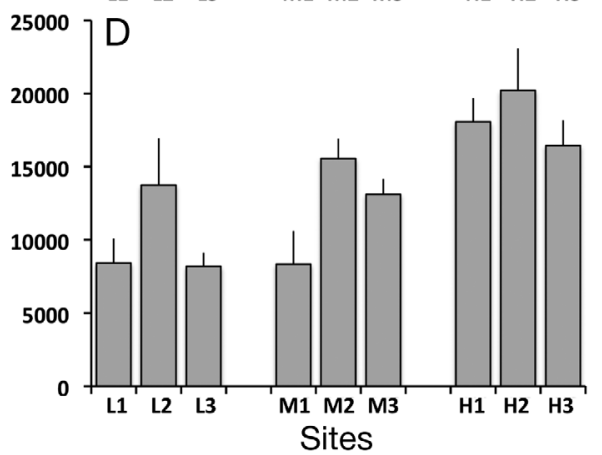

Fig. 7. Laminaria hyperborea. Biomass (freshweight, FW) of (A) holdfasts, (B) stipes, (C) blades and (D) total biomass at low (L1 to L3), intermediate (M1 to M3) and high (H1 to H3) wave exposure. Means + SE of 6 to 8 samples from each of 3 replicate stations within each level of exposure 
Table 6. Laminaria hyperborea. ANOVA testing the effect of wave exposure on the biomass ( $\mathrm{g} \mathrm{FW} \mathrm{m}^{-2}$; nested ANOVA) and production ( $\mathrm{g} \mathrm{FW} \mathrm{m}{ }^{-2} \mathrm{yr}^{-1}$; 1-way ANOVA) of holdfasts, stipes, blades and total biomass and production (wave exposure: $\mathrm{L}=$ low, $\mathrm{M}=$ intermediate, $\mathrm{H}=$ high)

\begin{tabular}{|c|c|c|c|c|c|c|c|}
\hline Parameter & Source of variation & $\mathrm{SS}_{\mathrm{III}}$ & df & MS & $F$ & $\mathrm{p}$ & Tukey \\
\hline \multicolumn{8}{|c|}{ Biomass (tested using nested ANOVA) } \\
\hline \multirow[t]{3}{*}{ Holdfast } & Exposure & 8.65 & 2 & 4.33 & 9.405 & 0.014 & $\mathrm{~L}=\mathrm{M}<\mathrm{H}$ \\
\hline & Site $_{(\exp )}$ & 2.76 & 6 & 0.46 & 1.912 & 0.094 & \\
\hline & Error & 13.71 & 57 & 0.24 & & & \\
\hline \multirow[t]{3}{*}{ Stipe } & Exposure & $3.32 \times 10^{8}$ & 2 & $1.66 \times 10^{8}$ & 10.860 & 0.010 & $\mathrm{~L}=\mathrm{M}<\mathrm{H}$ \\
\hline & Site $_{(\exp )}$ & $9.16 \times 10^{7}$ & 6 & $1.53 \times 10^{7}$ & 2.633 & 0.025 & \\
\hline & Error & $3.31 \times 10^{8}$ & 57 & $5.80 \times 10^{6}$ & & & \\
\hline \multirow[t]{3}{*}{ Blade } & Exposure & $6.60 \times 10^{7}$ & 2 & $3.30 \times 10^{7}$ & 4.564 & 0.062 & ns \\
\hline & Site $_{(\exp )}$ & $4.34 \times 10^{7}$ & 6 & $7.23 \times 10^{6}$ & 1.220 & 0.310 & \\
\hline & Error & $3.38 \times 10^{8}$ & 57 & $5.93 \times 10^{6}$ & & & \\
\hline \multirow[t]{3}{*}{ Total } & Exposure & $8.35 \times 10^{8}$ & 2 & $4.18 \times 10^{8}$ & 6.661 & 0.030 & $\mathrm{~L}=\mathrm{M}<\mathrm{H}$ \\
\hline & Site $_{(\exp )}$ & $3.76 \times 10^{8}$ & 6 & $6.27 \times 10^{7}$ & 1.969 & 0.085 & \\
\hline & Error & $1.82 \times 10^{9}$ & 57 & $3.18 \times 10^{7}$ & & & \\
\hline \multicolumn{8}{|c|}{ Production (tested using 1-way ANOVA) } \\
\hline \multirow[t]{2}{*}{ Holdfast } & Exposure & $6.99 \times 10^{5}$ & 2 & $3.50 \times 10^{5}$ & 22.644 & 0.002 & $\mathrm{~L}=\mathrm{M}<\mathrm{H}$ \\
\hline & Error & $9.26 \times 10^{4}$ & 6 & $1.54 \times 10^{4}$ & & & \\
\hline \multirow[t]{2}{*}{ Stipe } & Exposure & $8.98 \times 10^{6}$ & 2 & $4.49 \times 10^{6}$ & 10.980 & 0.010 & $\mathrm{~L}=\mathrm{M}<\mathrm{H}$ \\
\hline & Error & $2.45 \times 10^{6}$ & 6 & $4.09 \times 10^{5}$ & & & \\
\hline \multirow[t]{2}{*}{ Blade } & Exposure & $9.64 \times 10^{6}$ & 2 & $4.82 \times 10^{6}$ & 6.301 & 0.034 & $\mathrm{~L}=\mathrm{M}<\mathrm{H}$ \\
\hline & Error & $4.59 \times 10^{6}$ & 6 & $7.65 \times 10^{5}$ & & & \\
\hline \multirow[t]{2}{*}{ Total } & Exposure & $4.80 \times 10^{7}$ & 2 & $2.40 \times 10^{7}$ & 11.880 & 0.008 & $\mathrm{~L}=\mathrm{M}<\mathrm{H}$ \\
\hline & Error & $1.21 \times 10^{7}$ & 6 & $2.08 \times 10^{6}$ & & & \\
\hline
\end{tabular}

The mortality rate of sub-canopy plants was, in contrast, strongly correlated to the density of sub-canopy plants $(R=0.779, p=0.013)$, suggesting that intraspecific competition among these individuals is important. The reason why the mortality of subcanopy plants did not increase with increasing blade biomass of canopy plants may be that integrated light levels below the canopy were almost identical across levels of exposure due to a more frequent movement of the blades at high wave exposure (Wing et al. 1993). Light measurements within kelp populations at low- and high-exposure sites were carried out for other purposes in June 2006, and these data showed that only 2 to $3 \%$ of the surface light penetrated through the canopy but, more importantly, that the average light intensity $15 \mathrm{~cm}$ above the seafloor did not differ among sites with low and high wave exposure $(2.7 \pm 0.6 \%$ of incident surface insolation at low exposure versus $2.3 \pm 0.2 \%$ at high-exposure sites, M. F. Pedersen unpubl. data). Dense canopy layers may thus restrict light availability at the bottom and cause low survival among small Laminaria hyperborea, but changes in the blade biomass and shading regime may not be large enough to cause variations in recruit and sub-canopy mortality along the exposure gradient.

Few herbivores graze directly on kelp, and grazing is typically of marginal importance outside areas with a high abundance of sea urchins (Bartsch et al. 2008). Grazing by sea urchins can, however, reduce the survival of juvenile kelp in some cases (e.g. Dean et al. 1989, Sjøtun et al. 2006). The density and grazing pressure of sea urchins is inversely related to wave exposure (e.g. Sivertsen 1997), so grazer-mediated mortality should be most important at low-exposure sites, which could have masked the expected variations in juvenile mortality along the exposure gradient. The density of sea urchins (Echinus esculentus) in the study area was, however, extremely low (typically $<0.01 \mathrm{~m}^{-2}$ ) and did not vary visibly among study sites, so we find it unlikely that grazing substantially affected juvenile mortality rates.

The mobilization and transition of sub-canopy plants into the canopy stage is driven by the loss of canopy plants that free space for new, large individuals (Sjøtun et al. 2006). The absolute loss of canopy plants was similar (4 to 5 plants $\mathrm{m}^{-2} \mathrm{yr}^{-1}$ ) across levels of exposure, but the mortality rate tended to decrease with increasing wave exposure. This resulted in a higher steady-state density of canopy plants exposed to high wave energy. The low mortality rate among canopy plants at high wave exposure may therefore help explain the observed increase in biomass and production with increasing wave exposure. It is unclear why canopy plants should suffer higher rates of mortality at low wave 


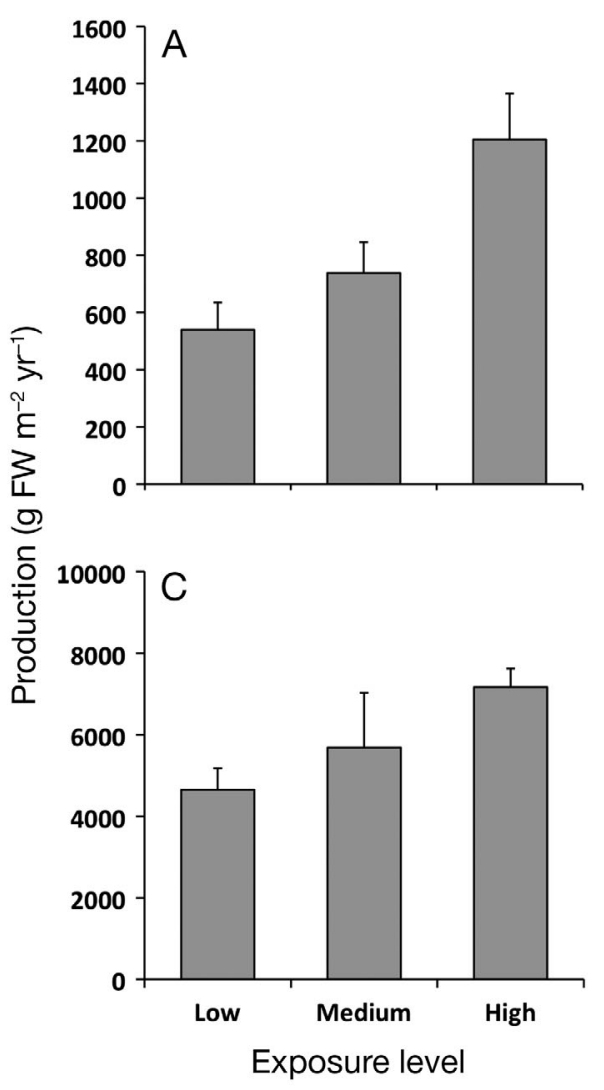

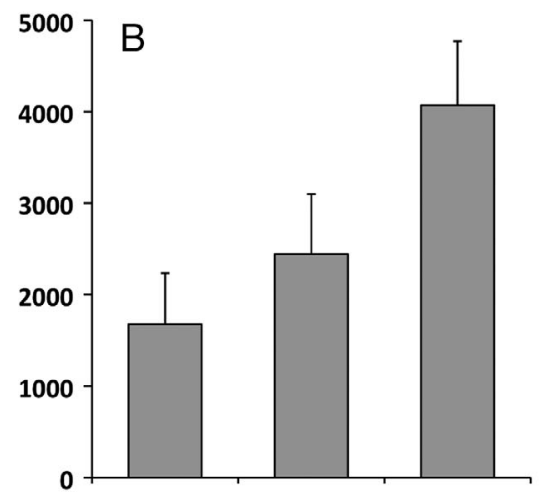

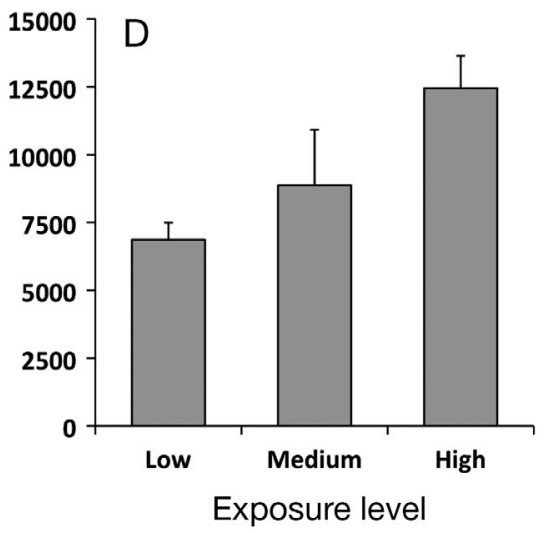

Fig. 8. Laminaria hyperborea. Annual production (freshweight, FW) of (A) holdfasts, (B) stipes, (C) blades and (D) total production at low (L), intermediate (M) and high (H) wave exposure. Means $+\mathrm{SD}$ of 3 replicate stations within each level of exposure exposure, but slow water motion may impede the acquisition of dissolved inorganic carbon and nutrients to an extent where it can affect growth and development (Hurd 2000). Most kelp species are, however, slow growing and therefore have low nutrient requirements per unit biomass and time, which reduces the risk of severe nutrient limitation (Pedersen \& Borum 1996, 1997, Pedersen et al. 2010). Another possibility is that the high mortality at low exposure was caused by epiphytes on the blades. The blades of canopy plants at low-exposure sites were heavily covered by epiphytes (mainly filamentous species, such as Ceramium virgatum and Polysiphonia elongata) in summer, a covering that was never seen on plants from the high-exposure sites. Epiphyte samples collected for other purposes showed that the epiphytic load (on blades of canopy plants) at low-exposure sites averaged $90 \pm 75 \mathrm{~g} \mathrm{FW}$ per blade (ca. $0.2 \mathrm{~g} \mathrm{FW} \mathrm{g}^{-1} \mathrm{FW}$ blade) but only $4 \pm 3 \mathrm{~g}$ FW per blade (or $0.006 \mathrm{~g} \mathrm{FW} \mathrm{g}^{-1} \mathrm{FW}$ blade) at highexposure sites (M. F. Pedersen unpubl. data). The high density of epiphytes on blades of canopy plants exposed to low wave exposure may interfere with the exchange of gasses, uptake of nutrients and light absorption and may, maybe more importantly, increase the surface and, thus, the drag imposed on these plants when subjected to water movement (Gaylord et al. 1994, Denny \& Gaylord 2002).

Plant density was affected by wave exposure, and plant size (and individual biomass) also increased with increasing exposure. Canopy plants from highexposure sites were almost $50 \%$ taller and ca. $75 \%$ heavier than those at low wave exposure. The change in plant size along the exposure gradient was caused by an increase in the biomass of the holdfast, stipe and blade. Morphology is affected by wave exposure in many kelp species (e.g. Kawamata 2001, Duggins et al. 2003, Roberson \& Coyer 2004, Wernberg \& Thomsen 2005). Adaptations typically include a proportionally larger holdfast and a thicker and sometimes shorter stipe, which reduces the chance of dislodgement, and smaller, slender and more streamlined blades that reduce the area exposed to the forces of moving water (Gaylord et al. 1994, Denny \& Gaylord 2002). Morphological adaptations to wave exposure in Laminaria hyperborea differ somewhat from this pattern because the plant tends to become taller and develop a larger biomass of the entire plant (including the blade), thus increasing the exposure to water motion rather than avoiding it (Svendsen \& Kain 1971, Sjøtun \& Fredriksen 1995, Sjøtun et al. 1998, present study). 
The reason why canopy plants become larger with increasing wave exposure remains unknown. It is tempting to explain the larger vigor of plants at high exposure by reduced boundary layers and faster acquisition of inorganic nutrients, but as discussed above, it seems unlikely that Laminaria hyperborea would suffer severe nutrient limitation under most conditions. Taller plants may instead result from intensified competition for light. The blade area of the canopy plants was $\sim 0.5$ to $0.8 \mathrm{~m}^{2}$ so the leaf area index (LAI) would range from ca. 5 at low exposure to ca. $7 \mathrm{~m}^{2} \mathrm{~m}^{-2}$ at high wave exposure (assuming an area to FW ratio of ca. $1 \mathrm{~m}^{2} \mathrm{~kg}^{-1} \mathrm{FW}$; Sjøtun et al. 1998), which corresponds to values reported for other populations of L. hyperborea (4.1 to $12.8 \mathrm{~m}^{2} \mathrm{~m}^{-2}$; Jupp \& Drew 1974). Increasing blade biomass (and thus LAI) leads to a higher degree of self-shading within the canopy layer, so increasing the stipe length may simply be an etiolation effect, i.e. an attempt to escape the intense competition for light within the canopy layer. Sjøtun et al. (1998) showed that stipe growth was positively correlated to canopy biomass in young L. hyperborea ( 2 and 3 yr old) but not in $4 \mathrm{yr}$ old plants that had reached the canopy. Stipe growth in these plants was instead correlated to wave exposure. Stipe length thus seems to be determined by a complex interaction between light conditions and wave exposure.

Larger blades combined with a higher plant density should, theoretically, intensify competition for light within the canopy layer. The largest possible blade biomass in the canopy layer is determined by the balance between benefits obtained by increasing light capture (through higher blade biomass) and the costs paid in terms of higher respiratory demands related to the larger biomass and increasing self-shading. Water motion, however, causes the blades to sway back and forth, which may reduce self-shading and allow a larger proportion of the canopy to be exposed to light on a daily basis. Frequent movement of the blades may therefore allow more exposed populations to maintain a larger canopy biomass, which may explain the higher density and size of plants as wave exposure increases. At low exposure, fouling by epiphytes and accumulation of silt on the blades may worsen the situation because both may substantially reduce the amount of light reaching the blades (Norton et al. 1977, Sand-Jensen et al. 1985). This could lower the diurnal carbon gain and thus, reduce plant fitness. Such plants would thus be even more sensitive to self-shading caused by high blade biomass, which may explain the lower density and smaller blades of canopy plants at low-exposure sites.
Acknowledgements. M.F.P. was supported by grant no. 2005-01-0522 from the Carlsberg Foundation, while L.B.N. was supported by grant no. 272-05-0161 (CIPE) from the Danish Natural Sciences Research Council. S.F., H.C. and K.M.N. were supported by grant no. 173468 from the Norwegian Research Council. We thank $T$. Bekkby (Norwegian Institute for Water Research) for providing estimated wave-exposure levels in the Molde archipelago and 2 anonymous referees for providing constructive criticism of the manuscript.

\section{LITERATURE CITED}

Abdullah MI, Fredriksen S (2004) Production, respiration and exudation of dissolved organic matter by the kelp Laminaria hyperborea along the west coast of Norway. J Mar Biol Assoc UK 84:887-894

Bartsch I, Wiencke C, Bischof K, Buchholz CM and others (2008) The genus Laminaria sensu lato: recent insights and developments. Eur J Phycol 43:1-86

Bekkby T, Isachsen PE, Isæus M, Bakkestuen V (2008) GIS modeling of wave exposure at the seabed: a depth-attenuated wave exposure model. Mar Geod 31: $117-127$

Bekkby T, Rinde E, Erikstad L, Bakkestuen V (2009) Spatial predictive distribution modelling of the kelp species Laminaria hyperborea. ICES J Mar Sci 66:2106-2115

Beverton RJH, Holt SJ (1957) On the dynamics of exploited fish populations. Fish Invest II 19: 5-533

Beverton RJH, Holt SJ (1959) A review of the lifespans and mortality rates of fish in nature, and their relation to growth and other physiological characteristics. Ciba Found Colloq Aging 5:142-180

- Borum J, Pedersen MF, Krause-Jensen D, Christensen PB, Nielsen K (2002) Biomass, photosynthesis and growth of Laminaria saccharina in a high arctic fjord, NE Greenland. Mar Biol 141:11-19

Christie H, Jørgensen NM, Norderhaug KM, WaageNielsen E (2003) Species distribution and habitat exploitation of fauna associated with kelp (Laminaria hyperborea) along the Norwegian coast. J Mar Biol Assoc UK 83:687-699

Creed JC, Kain JM, Norton TA (1998) An experimental evaluation of density and plant size in two large brown seaweeds. J Phycol 34:39-52

Davies CE, Moss D (2003) EUNIS habitat classification. European Topic Centre on Nature Protection and Biodiversity, Paris, available at http://eunis.eea.europa.eu/ habitats.jsp

> Dean TA (1985) The temporal and spatial distribution of underwater quantum irradiation in a southern California kelp forest. Est Coast Shelf Sci 21:835-844

Dean TA, Thies K, Lagos SL (1989) Survival of juvenile giant kelp: the effects of demographic factors, competitors, and grazers. Ecology (USA) 70:483-495

Denny MW, Gaylord B (2002) The mechanics of wave-swept algae. J Exp Biol 205:1355-1362

Duggins DO, Eckman JE, Siddon CE, Klinger T (2003) Population, morphometric and biochemical studies of three understory kelps along a hydrodynamic gradient. Mar Ecol Prog Ser 265:57-76

> Fredriksen S (2003) Food web studies in a Norwegian kelp forest based on stable isotope $\left(\delta^{13} \mathrm{C}\right.$ and $\left.\delta^{15} \mathrm{~N}\right)$ analysis. Mar Ecol Prog Ser 260:71-81 
Fredriksen S, Sjøtun K, Lein TE, Rueness J (1995) Spore dispersal in Laminaria hyperborea (Laminariales, Phaeophyceae). Sarsia 80:47-53

Gaylord B, Blanchette CA, Denny MW (1994) Mechanical consequences of size in wave-swept algae. Ecol Monogr 64:287-313

Gaylord B, Reed DC, Raimondi PT, Washburn L, McLean SR (2002) A physically based model of macroalgal spore dispersal in the wave and current-dominated nearshore. Ecology (USA) 83:1239-1251

Gaylord B, Reed DC, Raimondi PT, Washburn L (2006) Macroalgal spore dispersal in coastal environments: mechanistic insights revealed by theory and experiment. Ecol Monogr 76:481-502

> Gerard VA (1984) The light environment in a giant kelp forest: influence of Macrocystis pyrifera on spatial and temporal variability. Mar Biol 84:189-195

Graham MH, Harrold C, Lisin S, Light K, Watanabe JM, Foster MS (1997) Population dynamics of giant kelp Macrocystis pyrifera along a wave exposure gradient. Mar Ecol Prog Ser 148:269-279

Gundersen $H$, Christie $H$, de Wit $H$, Norderhaug KM, Bekkby T, Walday MG (2010) $\mathrm{CO}_{2}$ uptake in marine habitats - an investigation. Tracking no. OR-6070, Norwegian Institute for Water Research, Oslo (in Norwegian with an English summary)

Gunnarsson K (1991) Populations de Laminaria hyperborea et Laminaria digitata (Phéophycées) dans la baie de Breidifjördur, Islande. Rit Fiskideildar. J Mar Res Inst Reykjavik 12:1-148

Hurd CL (2000) Water motion, marine macroalgal physiology, and production. J Phycol 36:453-472

Isæus M (2004) Factors structuring Fucus communities at open and complex coastlines in the Baltic Sea. PhD dissertation, Stockholm University

> Jupp BP, Drew EA (1974) Studies on the growth of Laminaria hyperborea (Gunn) Fosl. I. Biomass and productivity. J Exp Mar Biol Ecol 15:185-196

Kain JM (1963) Aspects of the biology of Laminaria hyperborea. II. Age, weight and length. J Mar Biol Assoc UK 43:129-151

Kain JM (1967) Populations of Laminaria hyperborea at various latitudes. Helgol Meersunters 15:489-499

Kain JM (1971) Synopsis of biological data on Laminaria hyperborea. FAO Fish Synop 87:1-68

Kain JM (1975) The biology of Laminaria hyperborea. VII. Reproduction of the sporophyte. J Mar Biol Assoc UK 55: 567-582

Kawamata S (2001) Adaptive mechanical tolerance and dislodgement velocity of the kelp Laminaria japonica in waveinduced water motion. Mar Ecol Prog Ser 211:89-104

Leigh EG, Paine RT, Quinn JF, Suchanek TH (1987) Wave energy and intertidal productivity. Proc Natl Acad Sci USA 84:1314-1318

Lüning K (1969) Standing crop and leaf area index of the sublittoral Laminaria species near Helgoland. Mar Biol 3: 282-286

Lüning K (1990) Seaweeds. Their environment, biogeography, and ecophysiology. Wiley, New York, NY

> Norderhaug KM, Christie H, Fosså JH, Fredriksen S (2005) Fish-macrofauna interactions in a kelp (Laminaria hyperborea) forest. J Mar Biol Assoc UK 85:1279-1286

Norton TA, Hiscock K, Kitching JA (1977) The ecology of Lough Ine. XX. The Laminaria forest at Carrigathorna. J Ecol 65:919-941
Pedersen MF, Borum J (1996) Nutrient control of algal growth in estuarine waters. Nutrient limitation and the importance of nitrogen requirements and storage among phytoplankton and species of macroalgae. Mar Ecol Prog Ser 142:261-272

Pedersen MF, Borum J (1997) Nutrient control of estuarine macroalgae: growth strategy and the balance between nitrogen requirements and uptake. Mar Ecol Prog Ser 161:155-163

> Pedersen MF, Borum J, Fotel FL (2010) Phosphorus dynamics and limitation of fast- and slow-growing temperate seaweeds in Oslofjord, Norway. Mar Ecol Prog Ser 399: 103-115

Quinn GP, Keough MJ (2002) Experimental design and data analysis for biologists. Cambridge University Press, Cambridge

> Reed DC (1990) The effects of variable settlement and early competition on patterns of kelp recruitment. Ecology (USA) 71:776-787

> Reed DC, Foster MS (1984) The effects of canopy shading on algal recruitment and growth in a giant kelp forest. Ecology (USA) 65:937-948

Reed DC, Schroeter SC, Raimondi PT (2004) Spore supply and habitat availability as sources of recruitment limitation in giant kelp Macrocystis pyrifera (Phaeophyceae). J Phycol 40:275-284

Rinde E, Sjøtun K (2005) Demographic variation in the kelp Laminaria hyperborea along a latitudinal gradient. Mar Biol 146:1051-1062

Rinde E, Rygg B, Bekkby T, Isæus M, Erikstad L, Sloreid SE, Longva O (2006) Documentation of marine nature type models included in Directorate of Nature Management's database Naturbase. First generation models for the municipalities mapping of marine biodiversity 2007. Tracking no. 5321-2006, Norwegian Institute for Water Research, Oslo (in Norwegian with English abstract)

> Roberson LM, Coyer JA (2004) Variation in blade morphology of the kelp Eisenia arborea: incipent speciation due to local water motion? Mar Ecol Prog Ser 282: 115-128

Sand-Jensen K, Revsbech NP, Jørgensen BB (1985) Microprofiles of oxygen in epiphyte communities in submerged macrophytes. Mar Biol 89:55-62

Schoschina EV (1997) On Laminaria hyperborea (Laminariales, Phaeophyceae) on the Murman coast of the Barents Sea. Sarsia 82:371-373

- Sivertsen K (1997) Geographic and environmental factors affecting the distribution of kelp beds and barren grounds and changes in biota associated with kelp reduction at sites along the Norwegian coast. Can J Fish Aquat Sci 54:2872-2887

Sjøtun K, Fredriksen S (1995) Growth allocation in Laminaria hyperborea (Laminariales, Phaeophyceae) in relation to age and wave exposure. Mar Ecol Prog Ser 126: 213-222

Sjøtun K, Fredriksen S, Rueness J, Lein TV (1995) Ecological studies of the kelp Laminaria hyperborea (Gunnerus) Foslie in Norway. In: Skjoldal HR, Hopkins C, Erikstad KE, Leinaas HP (eds) Ecology of fjords and coastal waters. Elsevier, Amsterdam, p 525-536

Sjøtun K, Fredriksen S, Rueness J (1998) Effect of canopy biomass and wave exposure on growth in Laminaria hyperborea (Laminariaceae: Phaeophyta). Eur J Phycol 33:337-343 
Sjøtun K, Christie H, Fosså JH (2006) The combined effect of canopy shading and sea urchin grazing on recruitment in kelp forest (Laminaria hyperborea). Mar Biol Res 2: 24-32

Steneck RS, Graham MH, Bourque BJ, Corbett D, Erlandson JM, Estes JA, Tegner MJ (2002) Kelp forest ecosystems: biodiversity, stability, resilience and future. Environ Conserv 29:436-459

Svendsen P, Kain JM (1971) The taxonomic status, distribution, and morphology of Laminaria cucullata sensu Jorde

Editorial responsibility: Catriona Hurd,

Dunedin, New Zealand and Klavestad. Sarsia 46:1-22

Tala F, Edding M (2005) Growth and loss of distal tissue in blades of Lessonia nigrescens and Lessonia trabeculata (Laminariales). Aquat Bot 82:39-54

Wernberg T, Thomsen MS (2005) The effects of wave exposure on the morphology of Ecklonia radiata. Aquat Bot 83:61-70

Wing SR, Leichter JJ, Denny MW (1993) A dynamic model for wave-induced light fluctuations in a kelp forest. Limnol Oceanogr 38:396-407

Submitted: June 10, 2011; Accepted: January 12, 2012

Proofs received from author(s): April 2, 2012 